\title{
Spatial Patterns in the Association between the Prevalence of Asthma and Chronic Obstructive Pulmonary Disease: Socioeconomic and Climate Indicators in a Mediterranean Region
}

Carmen Bentué ( $\nabla$ cbentue@unizar.es)

University of Zaragoza: Universidad de Zaragoza https://orcid.org/0000-0002-7213-1718

Marcos Rodrigues Mimbrero

University of Lleida: Universitat de Lleida

Jose María Llorente González

Government of Aragon: Gobierno de Aragon

Antonio Sebastián Ariño

Government of Aragon: Gobierno de Aragon

Marcos Zuil Martín

Government of Aragon: Gobierno de Aragon

María Zúñiga Antón

University of Zaragoza: Universidad de Zaragoza

\section{Research}

Keywords: Asthma, COPD, GWR, prevalence, spatial analysis, mapping

Posted Date: August 3rd, 2021

DOl: https://doi.org/10.21203/rs.3.rs-757499/v1

License: (c) (i) This work is licensed under a Creative Commons Attribution 4.0 International License. Read Full License 


\section{Abstract}

The World Health Organization endorses the study of diseases from the perspective of the Determinants of Health (DH). DH are known as the circumstances in which people are born and raised, the environment in which they grow up and age and their lifestyle. The aim of this study is to analyze the spatial behavior of the prevalence of chronic obstructive pulmonary disease (COPD) and asthma in 2017 in Aragon, a Mediterranean region in Spain, using a DH approach. The methodological process entailed building a spatial database collating sociodemographic and climate indicators, and then evaluating the spatial variability of the relationships between $\mathrm{DH}$ indicators and disease prevalence by combining the Principal Component Analysis (PCA), Geographically Weighted Regression (GWR) models and cartographic design techniques. GWR evidences both global and spatially varying relationships, although each prevalence behaves differently. Asthma seems closely tied to local climate patterns whereas COPD is largely influenced by the built environment. Consequently, the socioeconomic and climatic contrasts characterizing the study area translate into several $\mathrm{DH}$ scenarios leading to situations vulnerable to the prevalence of asthma and COPD. This differential DH behavior detected by local regression models is relevant to guiding and refining public health decision-making.

\section{Background}

Goal 3.4 of the United Nations Sustainable Development Goals for 2030 aims to reduce premature mortality from noncommunicable diseases (e.g., depression, asthma, cancer and obesity) by at least one third. According to the World Health Organization (WHO), achieving such a goal poses a tough challenge given the increasing incidence and prevalence of this kind of diseases worldwide. Irrespective of the physiopathological traits of these diseases, the scientific community recognizes that the social and environmental settings in which people dwell, also known as Determinants of Health (DH), modulate the appearance and severity of these diseases. Therefore, healthcare, policymaking and management initiatives would strongly benefit from incorporating the $\mathrm{DH}$ perspective. These DHs and the prevalence of disease are not distributed homogeneously throughout the territory; they are linked to the living environment.

This study proposes a modeling approach that combines health geography and DH to assess spatial-explicit relationships between DHs and disease prevalence. The method is exemplified in Aragon (Spain) by leveraging the large data pool generated by the local, regional, and health administrations. We integrate this information into cartographic tools via Geographic Information Science and Technology (GIS\&T) and use Geographically Weighted Regression (GWR) as a methodological baseline to unravel spatially varying relationships and scale-dependent effects. GIS\&T allow for complex spatial analysis procedures, thus guiding the solution of specific problems in several areas: health management and primary-care orientation, territorial planning with a 'Health in All Policies' (HiAP) perspective focusing on health inequities or characterizing regions via health-related indicators (Cromley \& McLafferty, 2011). We extend the model to two inflammatory respiratory diseases with a high prevalence and a socioeconomic impact among citizens and on the healthcare system, namely asthma and chronic obstructive pulmonary disease (COPD).

Asthma is one of the most common major noncommunicable diseases and has a substantial impact on quality of life. The Global Burden of Disease study 2016 estimated that there were 339.4 million people worldwide affected by asthma, and according to the Global Asthma Report 2018, a further 100 million may be affected by 2025. In 2011, the WHO valued the cost of this disease in Europe at 38.3 billion euros (Gibson et al., 2013). In Spain, the annual asthma-related expenditure amounts to 1,533 euros per patient and year (Martínez-Moragón et al., 2009). 
The prevalence of asthma differs widely depending on the region studied; it varies from 2 percent in Tartu (Estonia) to 11.9 percent in Melbourne (Australia) (European Community Respiratory Health Survey [ECRHS], 2002). The prevalence in Spain varies, depending on the territory surveyed, from 1 (Huelva) to 4.7 percent (Albacete) (Cortés et al., 1998).

COPD is currently the fourth leading cause of death in the world and the WHO estimates that it will be the third leading cause by 2030 (WHO, 2010). In a document published in 2010, the WHO estimated that 210 million people in the world suffered from COPD (Bousquet et al., 2010). Investment in COPD treatment ranges from 9,730 to 43,785 euros depending on its severity (Sáenz et al., 2014). The average direct cost per COPD patient in Spain is estimated from 1,712 to 3,238 euros, annually. This direct cost is distributed into hospital expenses (40-45 percent), drugs (35-40 percent) and appointments and diagnostic tests (15-25 percent); indirect cost should be added to direct cost (Miravitlles et al., 2003). In Europe, prevalence varies from 2.1 to 26.1 percent depending on the country, the methods used to estimate prevalence, severity scales and population groups (Atsou et al., 2011), and it is expected to continue increasing until, at least, 2030 (Gibson et al., 2013). In Spain, the IBERPOC study (Sobradillo-Peña et al., 2000) reported a prevalence of 9.1 percent (14.3 percent in men and 3.9 percent in women) with significant differences based on geographical area, from only 4.9 percent in Cáceres to 18 percent in Manlleu (Barcelona), possibly related to environmental or occupational factors. New data on the current distribution of COPD from the EPI-SCAN study (Miravitlles et al., 2009) found a prevalence of COPD in the population aged 40-80 of 10.2 percent in Spain (15.1 percent in men and 5.7 percent in women).

In terms of medical personnel alone, both diseases in the US accounted for 12 billion dollars in 2017 (Syamlal et al., 2020). COPD and asthma are also broadly underdiagnosed with the literature documenting COPD underdiagnosis of up to 70 percent worldwide (Diab et al., 2018) and 74.7 percent in Spain (Soriano et al., 2021) and from 20 to 70 percent for asthma in Spain (Aaron et al., 2018).

The relationship between chronic respiratory diseases and socioeconomic and environmental variables has been recognized (Schulz \& Northridge, 2004; Marmot et al., 2012). This study provides evidence of local associations between respiratory diseases and socioeconomic and climate variables in Aragon, a Mediterranean region of southern Europe. The methods illustrated here allow us to develop a spatial-explicit baseline within the framework of health determinants that can be adapted to the particular aspects of any region elsewhere. We propose using spatially explicit models to analyze the spatial variability of associations between prevalence and $\mathrm{DH}$ indicators. The existence of multiscale relationships between disease prevalence and DH stresses the necessity of adopting a spatial-explicit perspective. Targeting the correct scale(s) toward the appropriate course of action improves effective decision-making in public health matters. Environmental and socioeconomic drivers operate at different spatial levels, demanding ad hoc responses. The proposed method was aimed at identifying such levels and outlining their spatial extent and relevance.

\section{Methods}

In the present study, a methodological procedure was developed and applied to evaluate whether there is spatial variability in the statistical association between the prevalence of COPD and asthma, and DH indicators. The methodology leverages GWR models (Fotheringham et al., 2002) as they can identify spatially varying relationships. GWR models can assess underlying patterns of association, translated into a set of local regression outputs. These methods have been used recently in the field of health geography, and previous studies on 
respiratory diseases, particularly asthma and COPD, have demonstrated their suitability for studying the spatial behavior of their prevalence using a DH approach (Kauhl et al., 2018; Kumarihamy et al., 2019; Guo et al., 2021).

\subsection{Study design: study area and participants}

The study area was established as the Autonomous Community of Aragon (Fig. 1). Aragon is a paradigmatic example of dissimilar population systems and environmental conditions. It contains a major metropolitan area with half the population, while low densely populated and rural settlements occupy the rest of the region. It shows contrasting climate patterns, from wet and cool conditions in the two surrounding mountain ranges (north and south of the region) to warm and dry situations in the central corridor of the River Ebro Valley (central sector of the province of Zaragoza in a north-west-south-east direction). This variety of situations may translate into differing levels of influence on the prevalence of the analyzed diseases.

The observational unit of our study was a Community Health Center ( $\mathrm{CHC}$ ), which is the territorial and administrative unit for primary healthcare in Aragon. The $\mathrm{CHC}$ is specifically designed to portray homogenous regions in terms of population and health-related services. The study encompasses $123 \mathrm{CHCs}$ grouped into eight sectors (Huesca, Barbastro, Zaragoza I, Zaragoza II, Zaragoza III, Teruel, and Alcañiz).

\subsection{Disease prevalence}

The Aragon Health Sciences Institute of the University of Zaragoza provided prevalence indicators of asthma and COPD. Prevalence was measured in cases per cent. Raw data consisted of diagnosed individuals from computerized records in primary care from 2005 to 2016. The criteria used to diagnose of asthma and COPD in Aragon are those recommended by the Spanish Society of Pulmonology and Thoracic Surgery (SEPAR) guidelines which are periodically updated and they are based on objective evidence (fundamentally spirometry and function tests). The data provided corresponded to people over 16 years and were checked by the researchers to avoid mistakes. Data were standardized into an adjusted prevalence rate to override potential bias among age or genderrelated groups. Standardized rates were calculated and spatialized at $\mathrm{CHC}$ level, later used as dependent variables in the regression analyses.

\subsection{Explanatory variables}

The core of the method lies in calibrating spatially explicit regression models. This calibration was performed by investigating the role of a series of health indicators based on the DH framework (Dahlgren \& Whitehead, 1991). We used a variety of social, demographic, economic and environmental variables potentially connected to the prevalence of asthma or COPD (Table 1). DH indicator data are freely available, retrieved from the Spanish Statistics Institute (INE, Spanish acronym), the Aragon Statistics Institute (IAEST, Spanish acronym), and the Spanish State Meteorological Agency (AEMET, Spanish acronym).

\subsection{Description of the models}

The evaluation of spatial variability in the statistical association between the prevalence of diseases and DHs was based on the combination of principal component analysis (PCA), GWR and multivariable maps.

Variables were submitted to PCA to summarize the original dataset (37 variables) into a smaller number of components (PCs). We applied PCA to variables in the socioeconomic and climate domains separately to preserve their intrinsic nature in the models and, thus, properly contextualize their effects. We selected those components 
accounting for at least 80 percent of cumulative variance, retaining those significantly correlated (Pearson's R) with at least one of the analyzed diseases for subsequent analyses.

The selected PCs were submitted to GWR models as predictors. GWR is a statistical technique for regession and exploratory analysis based on the spatial disaggregation of a global regression model into a set of spatially limited samples. GWR extends the traditional use of global regression models, through the assessment of local regression parameters. Analyzing the spatial behavior of different diseases from the DH approach allows us to assess whether the relationships are local (i.e., spatially varying across the region) or global (homogenous over the entire region). The following equation describes a conventional GWR mathematically:

$y_{i}=\Sigma_{k} \beta_{k}\left(u_{i}, v_{i}\right) x_{k} \cdot i+\varepsilon_{i}$

where $y_{i}, x_{k, i}$ and $\varepsilon_{i}$ are, respectively, a dependent variable, $k^{\text {th }}$ an independent variable, and the Gaussian error at location $i_{i}\left(u_{i}, v_{j}\right)$ is the $\mathrm{x}-\mathrm{y}$ coordinate of the $\mathrm{i}^{\text {th }}$ location; and coefficients $\beta\left(u_{i}, v_{i}\right)$ vary.

In GWR, a region is described around each observation location $i$ (with coordinates $u_{i}, v_{i}$ ) and all the data points within a given neighborhood window are used to calibrate a regression model. This process is repeated over all the candidate locations obtaining a set of local regression statistics as a result. GWR applies a distance weight pattern; hence, observations closer to the center of the window are weighted more heavily. We applied an adaptive kernel window, which varies in size (bandwidth or radius) according to the number of neighboring closest observations to be included. The adaptive approach is recommended when dealing with spatially clustered or imbalanced patterns, as is the case of $\mathrm{CHC}$ distribution.

The number of neighbors was optimized by minimizing the Akaike Information Criterion (AIC), adapted for GWR by Hurvich et al. (1998). A GWR model includes the usual outcomes of an ordinary least square regression model but grants an individual set per each location, in other words, it yields local regression parameters estimates instead of a unique set of global regression outputs (Brunsdon et al., 1996). This allows us to address the spatial pattern in beta coefficients or significance level of the predictors, or the percent of variance captured by the model $\left(R^{2}\right)$. Likewise, model inputs must fulfill the usual requirements of homoscedasticity, independence or normality of the covariates.

In this research, we employed the GWR 4.09 software (Nakaya, 2005). This particular version has several special features allowing testing for spatial variability (to determine the extent to which relationships vary spatially) and fit "mixed" models, in the sense of combining stationary and spatially varying covariates in a single GWR model. Two GWR explanatory models were fitted for asthma and COPD, separately. For each model we mapped the significance level and direction (either positive or negative) of each relationship (covariate) and the percent of variance explained (local $\mathrm{R}^{2}$ ).

Figure 1. Study area, administrative subdivisions and observational unit. 
Table 1

Explanatory variables: name, description and source.

\begin{tabular}{|c|c|c|c|c|c|c|c|}
\hline \multicolumn{4}{|c|}{ FUNCTIONALITY AND SOCIOECONOMIC VARIABLES } & \multirow{2}{*}{$\begin{array}{l}\text { Name } \\
\text { SEP }\end{array}$} & \multirow{2}{*}{$\begin{array}{l}\text { Variable } \\
\text { Separation, } \\
\text { divorce, or } \\
\text { widowhood }\end{array}$} & \multirow[b]{2}{*}{$\begin{array}{l}\text { Description } \\
\text { Ratio between } \\
\text { the number of } \\
\text { separated, } \\
\text { divorced, or } \\
\text { widowed } \\
\text { persons and } \\
\text { the total } \\
\text { number of } \\
\text { persons aged } \\
\text { over } 16 .\end{array}$} & \multirow{2}{*}{$\begin{array}{l}\text { Source } \\
\text { IGEAR }\end{array}$} \\
\hline TDI & $\begin{array}{l}\text { Territorial } \\
\text { Development } \\
\text { Index }\end{array}$ & $\begin{array}{l}\text { Synthetic index } \\
\text { of more than } 90 \\
\text { variables related } \\
\text { to economic, } \\
\text { demographic } \\
\text { and settlement } \\
\text { distribution } \\
\text { factors, as well } \\
\text { as factors } \\
\text { related to } \\
\text { accessibility to } \\
\text { facilities, } \\
\text { communications, } \\
\text { and natural } \\
\text { environment } \\
\text { components: } \\
\text { climate and } \\
\text { landscape. }\end{array}$ & IGEAR & & & & \\
\hline TF & $\begin{array}{l}\text { Territorial } \\
\text { Functionality }\end{array}$ & $\begin{array}{l}\text { Synthetic index } \\
\text { on the functional } \\
\text { hierarchy of } \\
\text { settlements in } \\
\text { Aragon. It } \\
\text { integrates } \\
\text { variables on } \\
\text { population } \\
\text { growth, } \\
\text { accessibility to } \\
\text { facilities, and } \\
\text { economic } \\
\text { activities. }\end{array}$ & IGEAR & H65 & $\begin{array}{l}\text { Households } \\
\text { with one } \\
\text { person over } \\
65\end{array}$ & $\begin{array}{l}\text { Ratio between } \\
\text { the number of } \\
\text { households } \\
\text { with one } \\
\text { person aged } \\
\text { over } 65 \text { and all } \\
\text { households. }\end{array}$ & INE \\
\hline ACC & $\begin{array}{l}\text { Accessibility of } \\
\text { Primary Care } \\
\text { Centers }\end{array}$ & $\begin{array}{l}\text { Average time (in } \\
\text { minutes) to } \\
\text { reach the nearest } \\
\text { primary-care } \\
\text { center. }\end{array}$ & IGEAR & H5P & $\begin{array}{l}\text { Households } \\
\text { with } 5 \text { or } \\
\text { more people }\end{array}$ & $\begin{array}{l}\text { Ratio between } \\
\text { the number of } \\
\text { households } \\
\text { with } 5 \text { or more } \\
\text { persons and } \\
\text { the total } \\
\text { number of } \\
\text { households. }\end{array}$ & INE \\
\hline COM & Communications & $\begin{array}{l}\text { Integrates } \\
\text { indicators related } \\
\text { to digital } \\
\text { communication, } \\
\text { namely the fiber } \\
\text { optic and } 4 G \\
\text { mobile coverage, } \\
\text { and access to } \\
\text { fixed or wireless } \\
\text { networks. }\end{array}$ & IGEAR & $\mathrm{BC}$ & $\begin{array}{l}\text { Building } \\
\text { condition }\end{array}$ & $\begin{array}{l}\text { Weighted } \\
\text { average of the } \\
\text { percentage of } \\
\text { buildings } \\
\text { based on their } \\
\text { condition in } \\
\text { accordance } \\
\text { with the } 2011 \\
\text { Population } \\
\text { and Housing } \\
\text { Census. }\end{array}$ & IAEST \\
\hline
\end{tabular}




\begin{tabular}{|c|c|c|c|c|c|c|c|}
\hline \multicolumn{4}{|c|}{ FUNCTIONALITY AND SOCIOECONOMIC VARIABLES } & \multirow{2}{*}{$\begin{array}{l}\text { Name } \\
\text { HE }\end{array}$} & \multirow{2}{*}{$\begin{array}{l}\text { Variable } \\
\text { Household } \\
\text { equipment }\end{array}$} & \multirow[b]{2}{*}{$\begin{array}{l}\text { Description } \\
\text { Weighted } \\
\text { average of the } \\
\text { percentage of } \\
\text { dwellings } \\
\text { based on their } \\
\text { facilities } \\
\text { according to } \\
\text { the } 2011 \\
\text { Population } \\
\text { and Housing } \\
\text { Census. }\end{array}$} & \multirow{2}{*}{$\begin{array}{l}\text { Source } \\
\text { IAEST }\end{array}$} \\
\hline FI & Femininity Index & $\begin{array}{l}\text { Expresses the } \\
\text { number of } \\
\text { women per } 100 \\
\text { men. }\end{array}$ & INE & & & & \\
\hline YDI & $\begin{array}{l}\text { Young } \\
\text { Dependency } \\
\text { Index }\end{array}$ & $\begin{array}{l}\text { Expresses the } \\
\text { ratio between the } \\
\text { population aged } \\
0-14 \text { and the } \\
\text { population aged } \\
15-64 \text {. }\end{array}$ & INE & LS & $\begin{array}{l}\text { Landscape } \\
\text { Factor }\end{array}$ & $\begin{array}{l}\text { Integrates } \\
\text { indicators } \\
\text { relating to the } \\
\text { quality of the } \\
\text { landscape, the } \\
\text { municipal area } \\
\text { included in a } \\
\text { Protected } \\
\text { Natural } \\
\text { Spaces } \\
\text { category, and } \\
\text { the presence } \\
\text { of approved } \\
\text { tourist trails. }\end{array}$ & IGEAR \\
\hline EDI & $\begin{array}{l}\text { Elderly } \\
\text { Dependency } \\
\text { Index }\end{array}$ & $\begin{array}{l}\text { Ratio between } \\
\text { the sum of the } \\
\text { population under } \\
15 \text { and over } 65 \\
\text { and the working } \\
\text { age population } \\
(16-64) \text {. }\end{array}$ & INE & LSQ & $\begin{array}{l}\text { Landscape } \\
\text { Quality }\end{array}$ & $\begin{array}{l}\text { Weighted } \\
\text { average value } \\
\text { of the quality } \\
\text { of landscape } \\
\text { types. }\end{array}$ & IGEAR \\
\hline LFS & $\begin{array}{l}\text { Labor Force } \\
\text { Structure } \\
\text { Index }\end{array}$ & $\begin{array}{l}\text { Ratio between } \\
\text { the population } \\
\text { aged } 16-39 \text { and } \\
\text { the population } \\
\text { aged } 40-64 \text {. }\end{array}$ & INE & OSLS & $\begin{array}{l}\text { Social } \\
\text { Appreciation } \\
\text { of the } \\
\text { Landscape }\end{array}$ & $\begin{array}{l}\text { Ratio between } \\
\text { the area } \\
\text { classified as } \\
\text { outstanding } \\
\text { (in hectares) in } \\
\text { relation to the } \\
\text { municipality } \\
\text { surface area. }\end{array}$ & IGEAR \\
\hline FP & $\begin{array}{l}\text { Foreign } \\
\text { Population }\end{array}$ & $\begin{array}{l}\text { Ratio between } \\
\text { the foreign } \\
\text { population and } \\
\text { the total } \\
\text { population. }\end{array}$ & INE & ATT & $\begin{array}{l}\text { Approved } \\
\text { Tourist Trails }\end{array}$ & $\begin{array}{l}\text { Presence of } \\
\text { approved } \\
\text { tourist trails in } \\
\text { the } \\
\text { municipality } \\
(\mathrm{km}) \text {. }\end{array}$ & IGEAR \\
\hline UNE & $\begin{array}{l}\text { Uneducated } \\
\text { population }\end{array}$ & $\begin{array}{l}\text { Ratio between } \\
\text { the total number } \\
\text { of persons aged } \\
16 \text { and over who } \\
\text { cannot read or } \\
\text { write in any } \\
\text { language and } \\
\text { the total } \\
\text { population of } \\
\text { this age group. }\end{array}$ & INE & CLIMAT & E VARIABLES & & \\
\hline
\end{tabular}




\begin{tabular}{|c|c|c|c|c|c|c|c|}
\hline \multicolumn{4}{|c|}{ FUNCTIONALITY AND SOCIOECONOMIC VARIABLES } & \multirow{2}{*}{$\begin{array}{l}\text { Name } \\
\text { XT }\end{array}$} & \multirow{2}{*}{$\begin{array}{l}\text { Variable } \\
\text { Maximum } \\
\text { Temperature }\end{array}$} & \multirow[b]{2}{*}{$\begin{array}{l}\text { Description } \\
\text { Monthly } \\
\text { average value } \\
\text { of maximum } \\
\text { temperatures. } \\
\text { Calculation } \\
\text { based on } \\
\text { dynamic } \\
\text { methods for } \\
\text { regionalization } \\
\text { of climate } \\
\text { models. }\end{array}$} & \multirow{2}{*}{$\begin{array}{l}\text { Source } \\
\text { AEMET }\end{array}$} \\
\hline STI & $\begin{array}{l}\text { Population with } \\
\text { First level } \\
\text { studies }\end{array}$ & $\begin{array}{l}\text { Ratio between } \\
\text { the total number } \\
\text { of persons aged } \\
16 \text { and over who } \\
\text { have not } \\
\text { completed ESO, } \\
\text { EGB or } \\
\text { elementary } \\
\text { baccalaureate } \\
\text { studies and the } \\
\text { total population } \\
\text { in this age group. }\end{array}$ & INE & & & & \\
\hline STII & $\begin{array}{l}\text { Population with } \\
\text { Second level } \\
\text { studies }\end{array}$ & $\begin{array}{l}\text { Ratio between } \\
\text { the total number } \\
\text { of persons aged } \\
16 \text { and over who } \\
\text { have completed } \\
\text { ESO, EGB or } \\
\text { elementary } \\
\text { baccalaureate } \\
\text { studies and the } \\
\text { total population } \\
\text { in this age group. }\end{array}$ & INE & MT & $\begin{array}{l}\text { Minimum } \\
\text { Temperature }\end{array}$ & $\begin{array}{l}\text { Monthly } \\
\text { average value } \\
\text { of minimum } \\
\text { temperatures. } \\
\text { Calculation } \\
\text { based on } \\
\text { dynamic } \\
\text { methods for } \\
\text { regionalization } \\
\text { of climate } \\
\text { models. }\end{array}$ & AEMET \\
\hline STIII & $\begin{array}{l}\text { Population with } \\
\text { Third level } \\
\text { studies }\end{array}$ & $\begin{array}{l}\text { Ratio between } \\
\text { the total number } \\
\text { of persons aged } \\
16 \text { and over who } \\
\text { have completed } \\
\text { university } \\
\text { studies and the } \\
\text { total population } \\
\text { in this age group. }\end{array}$ & INE & XT95 & $\begin{array}{l}\text { 95th } \\
\text { Percentile of } \\
\text { maximum } \\
\text { daily } \\
\text { temperature }\end{array}$ & $\begin{array}{l}\text { Annual 95th } \\
\text { percentile of } \\
\text { maximum } \\
\text { daily } \\
\text { temperature. } \\
\text { Calculation } \\
\text { based on } \\
\text { dynamic } \\
\text { methods for } \\
\text { regionalization } \\
\text { of climate } \\
\text { models. }\end{array}$ & AEMET \\
\hline UY & $\begin{array}{l}\text { Undereducated } \\
\text { Youth }\end{array}$ & $\begin{array}{l}\text { Ratio between } \\
\text { the number of } \\
\text { people aged 16- } \\
30 \text { who have not } \\
\text { completed } \\
\text { primary } \\
\text { education and } \\
\text { the total } \\
\text { population in } \\
\text { this age group. }\end{array}$ & IGEAR & MTO & $\begin{array}{l}\text { Number of } \\
\text { days with } \\
\text { minimum } \\
\text { temperature } \\
\text { below } 0^{\circ} \mathrm{C}\end{array}$ & $\begin{array}{l}\text { Annual } \\
\text { cumulative } \\
\text { number of } \\
\text { days with } \\
\text { minimum } \\
\text { temperature } \\
\text { below } 0^{\circ} \mathrm{C} \text {. } \\
\text { Calculation } \\
\text { based on } \\
\text { dynamic } \\
\text { methods for } \\
\text { regionalization } \\
\text { of climate } \\
\text { models. }\end{array}$ & AEMET \\
\hline
\end{tabular}




\begin{tabular}{|c|c|c|c|c|c|c|c|}
\hline \multicolumn{4}{|c|}{ FUNCTIONALITY AND SOCIOECONOMIC VARIABLES } & \multirow{2}{*}{$\begin{array}{l}\text { Name } \\
\text { AP }\end{array}$} & \multirow{2}{*}{$\begin{array}{l}\text { Variable } \\
\text { Accumulated } \\
\text { precipitation }\end{array}$} & \multirow[b]{2}{*}{$\begin{array}{l}\text { Description } \\
\text { Monthly } \\
\text { average } \\
\text { cumulative } \\
\text { precipitation. } \\
\text { Calculation } \\
\text { based on } \\
\text { dynamic } \\
\text { methods for } \\
\text { regionalization } \\
\text { of climate } \\
\text { models. }\end{array}$} & \multirow{2}{*}{$\begin{array}{l}\text { Source } \\
\text { AEMET }\end{array}$} \\
\hline UFP & $\begin{array}{l}\text { Undereducated } \\
\text { Foreign } \\
\text { Population }\end{array}$ & $\begin{array}{l}\text { Ratio of the } \\
\text { foreign } \\
\text { population that } \\
\text { has not } \\
\text { completed } \\
\text { primary } \\
\text { education and } \\
\text { the total foreign } \\
\text { population. }\end{array}$ & IGEAR & & & & \\
\hline PI & $\begin{array}{l}\text { Privation } \\
\text { Index }\end{array}$ & $\begin{array}{l}\text { Synthetic index } \\
\text { of the } \\
\text { percentage of } \\
\text { unemployment, } \\
\text { temporary } \\
\text { employees, and } \\
\text { insufficient } \\
\text { education. }\end{array}$ & IGEAR & P20 & $\begin{array}{l}\text { Number of } \\
\text { days with } \\
\text { precipitation } \\
\text { over } 20 \mathrm{~mm}\end{array}$ & $\begin{array}{l}\text { Monthly } \\
\text { cumulative } \\
\text { number of } \\
\text { days with } \\
\text { precipitation } \\
\text { over } 20 \mathrm{~mm} \text {. } \\
\text { Calculation } \\
\text { based on } \\
\text { dynamic } \\
\text { methods for } \\
\text { regionalization } \\
\text { of climate } \\
\text { models. }\end{array}$ & AEMET \\
\hline RU & $\begin{array}{l}\text { Rate of } \\
\text { Unemployment }\end{array}$ & $\begin{array}{l}\text { Ratio between } \\
\text { the total } \\
\text { unemployed } \\
\text { population aged } \\
\text { over } 15 \text { and the } \\
\text { total employed } \\
\text { and unemployed } \\
\text { job seekers. }\end{array}$ & IGEAR & P1 & $\begin{array}{l}\text { Number of } \\
\text { days with } \\
\text { precipitation } \\
\text { under } 1 \mathrm{~mm}\end{array}$ & $\begin{array}{l}\text { Monthly } \\
\text { cumulative } \\
\text { number of } \\
\text { days with } \\
\text { precipitation } \\
\text { under } 1 \mathrm{~mm} \text {. } \\
\text { Calculation } \\
\text { based on } \\
\text { dynamic } \\
\text { methods for } \\
\text { regionalization } \\
\text { of climate } \\
\text { models. }\end{array}$ & AEMET \\
\hline MI & $\begin{array}{l}\text { Median } \\
\text { Income }\end{array}$ & $\begin{array}{l}\text { Expresses the } \\
\text { average wage of } \\
\text { each inhabitant } \\
\text { (ratio between } \\
\text { earnings and } \\
\text { salaries), in } \\
\text { thousands of } \\
\text { euros. }\end{array}$ & IGEAR & RH & $\begin{array}{l}\text { Relative } \\
\text { Humidity }\end{array}$ & $\begin{array}{l}\text { Monthly } \\
\text { average } \\
\text { relative } \\
\text { humidity. } \\
\text { Calculation } \\
\text { based on } \\
\text { statistical } \\
\text { methods for } \\
\text { regionalization } \\
\text { of climate } \\
\text { models. }\end{array}$ & AEMET \\
\hline BAC & Bachelorhood & $\begin{array}{l}\text { Ratio between } \\
\text { the number of } \\
\text { single persons } \\
\text { and the total } \\
\text { number of } \\
\text { persons aged } \\
\text { over } 16 .\end{array}$ & IGEAR & WS & $\begin{array}{l}\text { Wind speed } \\
\text { at } 10 \mathrm{~m}\end{array}$ & $\begin{array}{l}\text { Monthly } \\
\text { average wind } \\
\text { speed at } 10 \mathrm{~m} \text {. } \\
\text { Calculation } \\
\text { based on } \\
\text { statistical } \\
\text { methods for } \\
\text { regionalization } \\
\text { of climate } \\
\text { models. }\end{array}$ & AEMET \\
\hline
\end{tabular}




\section{Results}

\subsection{Disease prevalence and explanatory factors}

The prevalence of asthma in Aragon ranged from 3.1 to 9.7 cases per hundred (Fig. 3). Asthma prevalence was higher in urban settlements, such as the metropolitan area of Zaragoza or Huesca; industrial sites (Sabiñánigo, Barbastro and Monzón); and the central corridor along the River Ebro Valley (from Tarazona to the southeastern $\mathrm{CHCs}$ of the Alcañiz health sector). In the case of the prevalence of COPD, the sectors with the lowest rates (0.35 percent) were located in Barbastro and Huesca, while the highest prevalence rates (2.5 percent) observed in the western and eastern edges of the province of Zaragoza and Teruel, respectively.

\subsection{Key explanatory factors}

We initially retained seven components from the socioeconomic domain and two from the climate domain. Given the observed association between disease prevalence and PCs (Table 2), we selected the first, third and seventh components of the functionality and socioeconomic block (S1 and S7), and the first and second components of the climate block ( $\mathrm{C} 1$ and $\mathrm{C} 2$ ) as explanatory factors of asthma. The same components were selected in the case of COPD, adding the third socioeconomic component (S3) to the explanatory factor pool. See Table 3 for a detailed description of the selected PCs and their role and meaning. PCs were labeled to facilitate interpretation:

- Functionality (P1). This indicator relates to the functional hierarchy in Aragon. High values denoted an advantageous situation in terms of accessibility, communications, services, and vice versa. Higher proportions of women, single young people, and higher levels of training are also associated with this component.

- Demographic structure (P3). This correlates positively with the elderly dependency ratio and percentage of households with one person aged over 65 . It is negatively correlated with youth dependency ratio, labor force index, foreign people, and privation indicators. It illustrates a context of vulnerability linked to overaged demographic structures.

- Social environment (P7). High scores point toward communities with unemployed local populations whereas low values relate to increased foreign people with basic education and sharing lodging. Both high and low values of the component can illustrate a context of vulnerability.

- Water balance (C1). High index scores indicate wet and cool conditions and vice versa.

- Climate extremes (C2). This relates to unusual hazardous weather conditions and extreme events such as torrential rainfall, strong winds or heat waves.

Figure 3. Spatial distribution of asthma and COPD prevalence.

Figure 4. Spatial distribution of asthma and COPD prevalence.

\subsection{Modeling outputs and spatial effects}

Due to collinearity between socioeconomic and climate indicators, two separate models were calibrated (Table 4). Asthma models exploring socioeconomic indicators (see model 1 in Table 4 and Fig. 5) revealed a non-stationary behavior of "functionality" and a global relationship with the "social environment", with a positive direction of the association in the first case and negative in the second. With an optimal bandwidth of 80 out of $123 \mathrm{CHCs}$, the model attained an average $R^{2}$ of 0.44 , reaching 0.57 in the southwest of Zaragoza province and in the northeast of Teruel province. The significance level $(p<0.05)$ covers practically the entire region. 
Climate models combining "water balance" and "climate extremes" (model 2) suggested a spatially varying influence of both indicators on the prevalence of asthma. The model reached an average $\mathrm{R}^{2}$ of 0.51 , and the direction of the association was negative in the first case and negative in the second. The local behavior of climate was emphasized by its lower bandwidth (57 neighboring $\mathrm{CHCs}$ ) and the fact that both indicators significantly varied over space. Local $R^{2}$ increases (from 0.40 up to 0.69) from the north and southwest of Zaragoza province to the eastern end of the province of Teruel (Fig. 5). In the case of "water balance", the patterns of significance shift toward the province of Teruel, while for "climate extremes", the significance shifts toward the east of this province, in the Alcañiz health sector.

Concerning COPD (model 3), "functionality" performed better as a local covariate (70 CHCs) with a positive direction of association and an average $\mathrm{R}^{2}$ of 0.42 , peaking in the eastern of Zaragoza and south of Huesca provinces (0.62) and patterns of significance drawn in practically the entire region (Fig. 5). In turn, while maintaining the direction of the association, a global relationship was observed between the prevalence and the "demographic structure" and "social environment" indicators (Table 4). COPD model 4 revealed the better performance of "demographic structure" and "water balance" indicators as global variables, with a negative direction of association and reaching an $\mathrm{R}^{2}$ of 0.38 (Table 4 ).

Table 2

Correlogram of disease prevalence and PCs (Pearson's R). Bold indicates strong association with prevalence indicators. Correlations highlighted in red indicate collinearity between PCs.

\begin{tabular}{|llllllll|}
\cline { 1 - 2 } CO & 0.35 & & & & & & \\
COPD & & & & \\
P1 & 0.52 & 0.26 & P1 & & & \\
P3 & -0.15 & -0.31 & -0.15 & P3 & & \\
P7 & $\mathbf{0 . 2 8}$ & $\mathbf{0 . 3 2}$ & 0.01 & -0.02 & P7 & \\
C1 & -0.52 & -0.31 & -0.62 & 0.09 & 0.01 & C1 \\
C2 & $\mathbf{0 . 3}$ & -0.27 & 0.3 & 0.07 & -0.23 & -0.25 \\
\hline
\end{tabular}


Table 3

Description of the selected PCs. \%Var indicates the proportion of variance within the block gathered by the PC. Sign indicates the direction of the association between the original variables (only those with EigVal > 0.2 were shown) and PCs. EigVal denotes the correlation value between the original variables and the PCs.

Variables show the name of the original variables as reported in Table 1.

\begin{tabular}{|c|c|c|c|c|c|}
\hline PC & CP Indicator & $\% \mathrm{~V}$ & Sign & EigVal & Name \\
\hline \multirow[t]{6}{*}{1} & Functionality & 0.39 & - & 0.26 & STI \\
\hline & & & - & 0.25 & UED \\
\hline & & & - & 0.24 & UNE \\
\hline & & & + & 0.27 & TF \\
\hline & & & + & 0.28 & COM \\
\hline & & & + & 0.28 & $\mathrm{BC}$ \\
\hline \multirow[t]{5}{*}{3} & Demographic structure & 0.09 & - & 0.40 & LFS \\
\hline & & & - & 0.35 & YDI \\
\hline & & & - & 0.29 & PRI \\
\hline & & & + & 0.30 & $\mathrm{H} 65$ \\
\hline & & & + & 0.37 & EDI \\
\hline \multirow[t]{5}{*}{7} & Social environment & 0.03 & - & 0.55 & H5P \\
\hline & & & - & 0.47 & $\mathrm{FP}$ \\
\hline & & & - & 0.31 & STIII \\
\hline & & & + & 0.26 & $\mathrm{RU}$ \\
\hline & & & + & 0.29 & STII \\
\hline \multirow[t]{6}{*}{1} & Water balance & 0.78 & - & 0.33 & $95 \times T$ \\
\hline & & & - & 0.33 & $\mathrm{XT}$ \\
\hline & & & - & 0.33 & $\mathrm{P} 1$ \\
\hline & & & + & 0.32 & AP \\
\hline & & & + & 0.32 & MTO \\
\hline & & & + & 0.32 & $\mathrm{RH}$ \\
\hline \multirow[t]{4}{*}{2} & Climate extremes & 0.11 & - & 0.46 & WS \\
\hline & & & - & 0.20 & MTO \\
\hline & & & + & 0.41 & TRO \\
\hline & & & + & 0.50 & P95PP \\
\hline
\end{tabular}


Table 4

Summary of GWR outputs: local and global variables, model performance $\left(\mathrm{R}^{2}\right)$ and bandwith.

\begin{tabular}{|llllll|}
\hline Model & Disease & Local variables & $\begin{array}{l}\text { Global } \\
\text { variables }\end{array}$ & $\mathbf{R}^{2}$ & $\begin{array}{l}\text { Band- } \\
\text { width }\end{array}$ \\
\hline 1 & Asthma & $\mathrm{P} 1$ & $\mathrm{P} 7$ & 0.44 & 80 \\
\cline { 4 - 6 } 2 & & $\mathrm{C} 1, \mathrm{C} 2$ & - & 0.51 & 57 \\
\hline 3 & COPD & $\mathrm{P} 1$ & $\mathrm{P} 3, \mathrm{P} 7$ & 0.42 & 70 \\
\hline 4 & & - & $\mathrm{P} 3, \mathrm{C} 1$ & 0.38 & - \\
\hline
\end{tabular}

\section{Discussion}

According to the Spanish Guidelines on the Management of Asthma (Plaza et al., 2016), asthma is a syndrome including several clinical phenotypes sharing similar clinical features with probably different etiologies. However, according to the Global Initiative for Asthma Management and Prevention 2020 (Rajan et al., 2020), it is a heterogeneous disease and phenotypes do not correlate strongly with specific pathological processes or treatment responses. Both guides agree, though, on the strong association with airways inflammation and hyperresponsiveness.

The origin of asthma is not totally known. Its relationship with allergen exposure, environmental tobacco smoke, obesity, dietary habits, family size, and access to health, among others, has been demonstrated (Bhattacharjee et al., 2018). However, other factors have not been clarified yet. As occurs with other diseases, the development of asthma remains complex and incompletely understood. There is interplay between genetic predisposition and environmental exposures (Anderson \& Jackson, 2017) and it is, also important to consider that some factors foster the appearance of asthma while others trigger symptoms or exacerbations.

The prevalence of physician-diagnosed asthma in Aragon ranged from 3.1 to 9.7 cases per hundred. We appreciate huge prevalence differences depending on the areas studied. These differences also occur in other studies. In a survey developed and implemented by the WHO in 2002-2003 a total of 178,215 individuals from 70 countries aged 18 to 45 were studied and the researchers found the global prevalence rates of physician-diagnosed asthma, clinical/treated asthma, and wheezing in adults were 4.3, 4.5, and 8.6 percent, respectively, and varied by as much as 21 -fold among the 70 countries (To T et al., 2012). Moreover, problems with diagnosis precision among primarycare health services caused under (54 percent) or overdiagnosis (34 percent) (José et al., 2014).

The prevalence of asthma has increased worldwide from 1990 to 2015 by 12.6 percent. In contrast, the agestandardized mortality rate has decreased by almost 59 percent over the same period (GBD Chronic Respiratory Disease Collaborators, 2017). The rise in asthma prevalence is most likely caused by changes in the environment, since it is unlikely that the population's genetic background has recently changed (Koppelman, 2006), it affects mainly middle-aged people, especially women, and has been explained by an increase in allergic asthma (Lundbäck et al., 2016). We know that the geographical distribution of the pollen species is strongly influenced by geoclimatic conditions, which contributes to the sensitization pattern of patients (Bousquet et al., 2007), and that exposure to pollen grains increases the risk of asthma exacerbations among asthmatic patients (Darrow et al., 2012; Kitinoja et al., 2020). Both indoor (biomass) and outdoor (fossil fuels) pollution are risk factors for asthma 
and trigger symptoms and exacerbations (WHO, 2016; Health Effects Institute, 2019). Taken together, these data suggest the prevalence of asthma will change in the future in Aragon, at least in response to environmental changes resulting from human activity, which will pose a challenge for social and health strategies.

According to the Global Initiative for Chronic Obstructive Lung Disease (GOLD), COPD is a common, preventable, and treatable disease characterized by persistent respiratory symptoms and airflow limitation that is due to airway and/or alveolar abnormalities usually caused by significant exposure to noxious particles or gases (Vogelmeier et al., 2017). The fourth leading cause of death in the world (Lozano et al., 2012), it is projected to increase in the next decades (Mathers \& Loncar, 2006). Although the main risk factor is tobacco smoking, other exposures to air pollution or biomass fuel may be important.

A systematic review estimated the prevalence of COPD in the general population to be about 1 percent at all ages, increasing to 8-10 percent or higher in adults aged 40 or older (Halbert et al., 2006).

The study conducted by Sobradillo-Peña et al. (2000) in Spain reported a prevalence of 9.1 percent with significant differences based on geographical area, rates from 4.9 to 18 percent in provinces of Spain. The ARAPOC study in Aragon found a mean prevalence of 10.4 percent ( $\mathrm{Cl} 9.8-11.0$ percent) in the population aged 40-75, 16.9 percent in men, and 5.7 percent in women. Our data suggest that the variable behavior between territories observed large scale can be reproduced in smaller territories. We observed rates in the general population from 0.35 to 2.5 cases per hundred.

A survey (2012-2015) in the USA of 90,334 adults ( $\geq 40$ years old) showed a prevalence of COPD of 15.4 percent in poor rural areas compared with 8.4 percent in the overall population (Raju et al., 2019). Rural residence and census-level poverty were independent risk factors. The authors stressed the need for research to elucidate contributors to COPD development in poor and rural areas, including assessments of heating sources and environmental pollutants. In summary, some aspects explaining the differences in the prevalence of asthma and COPD between different regions still need to be clarified. A better understanding of the geographical determinants will lead to better resource management.

In the present study, we built and exploited a cross-sectional spatial database including socioeconomic, demographic, and climate factors to identify spatial-dependence associations with disease prevalence. We found that the "social environment" systematically promotes higher vulnerability to asthma and COPD over the entire region, and that it is associated with risk factors such as unemployment and educational level, among others. These associations are consistent with previous studies (Ellison-Loschmann et al., 2007; Gershon et al., 2012). In the latter (COPD) the "demographic structure" indicator reveals a global increase in prevalence rates linked to spaces with overaged demographic structures and low education level, known to be related with increased tobacco consumption (Miravitlles et al., 2009).

Conversely, the "functionality" indicator displayed a positive, though local, association with increased incidence of asthma and COPD associated with urban spaces (Scherber et al., 2014; Douglas et al., 2019), the proximity to industrial sites or occupational asthma and COPD (Sunyer et al., 1997; Dodd et al., 2020). For instance, CHCs with an industrial predominant activity such as Sabiñánigo and Monzón, Calatayud, the River Ebro Valley and Andorra, Utrillas and Caspe surroundings denote higher rates of prevalence. The importance of socioeconomic and labor factors is well known, particularly in rural areas, which can be underestimated in population studies (Soumagne et al., 2020). 
Climate indicators showed a differential behavior between both diseases. Asthma's relationship with "water balance" is negative and with "climate extremes" it is positive, and in both cases, it is spatially varying. The negative relationship indicates an increase in prevalence matching the thermal contrasts and the higher incidence of tropical nights. The positive relationship relates to sudden changes in weather conditions such as strong winds, altered rainfall and temperature oscillations. GWR outputs (Fig. 5) show a dragging effect of significance and magnitude from Campo de Belchite and Híjar health sectors to Alcañiz. We believe this local association in this eastern sector of the River Ebro depression concerns acute water deficit fostering parched conditions, thus hampering breathing. Studies such as the one by George et al. (2017) suggest higher vulnerability to asthma with increasing temperatures and climate extremes.

In the case of COPD, "water balance" showed a negative association within prevalence at a global scale. Thus, extreme heat and dry conditions (heat waves and drought) could promote increased COPD prevalence (Hansel et al., 2016). Future studies should also pay attention to extreme cold events during the winter season such as those of Jenkins et al. (2012) and Gayle et al. (2021).

The studies on asthma and COPD conducted by Kauhl et al. (2018), Kumarihamy et al. (2019), and Guo et al. (2021) reveal similar associations, confirming the suitability of GWR-like models opposed to global alternatives. However, not all GWR approaches work equally well. In the study by Guo et al. (2021) the geographical and temporal weighted regression (GTWR) outperformed the "traditional" GWR approaches (Kumarihamy et al., 2019; Kauhl et al., 2018).

\section{Conclusions}

In our study, the "mixed" version of the GWR enabled further insights into scale effects by differentiating (and coupling) the global or local character of the covariates, which are forced to be nonstationary (both temporally and spatially) in the aforementioned approaches. The "mixed" GWR approach seems particularly suitable for addressing regions with contrasting settings, e.g., complex reliefs, contrasting patterns of population distribution or local climate and weather conditions. The adaptive kernel strategy with biquadratic weighting used was able to overcome the pronounced macrocephaly of the study region (more densely populated around the urban $\mathrm{CHCs}$ of ZGZ and dispersed in the rest). In short, the strength of the model lies in its capability to overcome the differential behavior of the disease prevalence and its determinants and their statistical association. Altogether, this contributes to improved decision-making in public health matters by adjusting the scale of the problem to that of the actions required.

One of the study's limitations, due to the development of a spatial study system, is data on COPD, which have been correlated with the spatial situation of people and should also have been completed with specific data on nonsmokers, smokers, and former smokers. Future developments of new studies should include this aspect.

Another limitation is that we have not been able to obtain data on children under 16, which excludes childhood asthma. Prevalence is calculated at the general population level and, therefore, should not be compared with other epidemiological studies as the methodology is different. The aim of this study was to assess the variability of prevalence distribution at smaller levels.

A common drawback in epidemiological studies is the divergence of results depending on the diagnostic method used. In fact, there is no consensus on the definition of these two diseases among scientific societies.

Page 15/28 
In the present study, data obtained from diagnoses made by both primary-care and specialist physicians were used. The recommendations of the Spanish guidelines (GEMA, 2009; Miravitlles et al., 2014), which combine clinical data with objective measures, are followed in both primary and specialized care. In Aragon, a computer program $(\mathrm{OMI})$ is used, which requests data obtained on pulmonary function (spirometry, bronchial reversibility study) and adds this to the clinical picture (symptoms, previous exposure) to diagnose both COPD and asthma; this minimizes the possibility of overdiagnosis. In any case, a recent article evaluating the results of the Spanish part of the European Community Respiratory Health Survey (ECRHS) concludes an increase in asthma diagnoses and treatments that does not correspond to an increase in symptoms, indicating that physicians are more willing to diagnose and treat this disease (Urrutia et al., 2007). Underdiagnosis is more difficult to overcome; however, all primary-care centers in the region have spirometry equipment, and the network of health centers covers the entire population of Aragon with sufficient proximity, thus limiting the underdiagnosis bias to some extent.

One of the strengths of our study design is that it avoids participation biases that are inevitable in epidemiological studies and offers the possibility of examine health determinants in rural areas.

\section{Abbreviations}

DH - Determinants of Health

COPD - Chronic Obstructive Pulmonary Disease

PCA - Principal Component Analysis

GWR - Geographically Weighted Regression

WHO - World Health Organization

GIS\&T - Geographic Information Science and Technology

CHC - Community Health Center

SEPAR - Spanish Society of Pulmonology and Thoracic Surgery

INE - Spanish Statistics Institute

IAEST - Aragon Statistics Institute

AEMET - Spanish State Meteorological Agency

PC - Principal Components

AIC - Akaike Information Criterion

GTWR - Geographical and Temporal Weighted Regression

ECRHS - European Community Respiratory Health Survey

\section{Declarations}




\section{- Ethics approval and consent to participate}

The study is approved by the Research Ethics Committee of the Autonomous Community of Aragon (CEICA, Spanish acronym).

- Consent for publication: not applicable.

- Availability of data and materials

The datasets generated and/or analysed during the current study are not publicly available due to personal data protection regulations but are available from the corresponding author on reasonable request and with permission of the Research Ethics Committee of the Autonomous Community of Aragon (CEICA, Spanish acronym).

- Competing interests: none

- Funding

- Project partially funded by the European Regional Development Fund (FEDER) within the framework of the Program Interreg V-A Spain-France-Andorra (POCTEFA 2014-2020). Innovation Projects and Transfer of Results in R\&D (PITRID) framed in the Refbioll project: "GEOSIGEPOC-ASMA: Integration of cartographic tools and spatial perspective in health information systems: Design and application to the pilot study of the prevalence of COPD and Asthma in the Autonomous Community of Aragon (Spain) ".

- Project partially funded by Young Research Program of the University of Zaragoza: "Integration of cartographic tools and spatial analysis in health information systems: Design, validation and application to the study of the prevalence of depression, asthma, COPD and diabetes in Aragon".

- Gobierno de Aragon. Predoctoral Fellowship granted to Carmen Bentué Martínez.

\section{- Authors' contributions - CRediT statements}

Carmen Bentué: Conceptualization, Methodology, Investigation, Writing - Original Draft, Visualization

Marcos Rodrigues: Conceptualization, Methodology, Investigation, Software, Validation, Formal analysis, Data Curation, Writing - Review \& Editing, Supervision

Jose $\mathrm{M}^{\mathrm{a}}$ Llorente: Conceptualization, Writing - Review \& Editing

Antonio Sebastián: Conceptualization, Writing - Review \& Editing

Marcos Zuil: Conceptualization, Writing - Review \& Editing

María Zúñiga: Conceptualization, Methodology, Investigation, Resources, Writing - Review \& Editing, Supervision, Project administration, Funding acquisition

\section{- Acknowledgements}

Institute for Research in Environmental Sciences (IUCA), University of Zaragoza.

\section{References}


Aaron, S. D., Boulet, L. P., Reddel, H. K., \& Gershon, A. S. (2018). Underdiagnosis and overdiagnosis of asthma. American journal of respiratory and critical care medicine, 198(8), 1012-

1020. https://doi.org/10.1164/rccm.201804-0682Cl

Anderson, H. M., \& Jackson, D. J. (2017). Microbes, allergic sensitization, and the natural history of asthma. Current opinion in allergy and clinical immunology, 17(2), 116-122. https://doi.org/10.1097/ACI.0000000000000338

Atsou, K., Chouaid, C., \& Hejblum, G. (2011). Variability of the chronic obstructive pulmonary disease key epidemiological data in Europe: systematic review. BMC medicine, 9, 7. https://doi.org/10.1186/1741-7015-9-7

Bhattacharjee, S., Haldar, P., Gopal Maity, S., Debnath, S., Moitra, S., Saha, S., Mitra, R., Annesi-Maesano, I., GarciaAymerich, J., \& Moitra, S. (2018). Prevalence and Risk Factors of Asthma and Allergy-Related Diseases among Adolescents (PERFORMANCE) study: rationale and methods. ERJ open research, 4(2), 00034-

2018. https://doi.org/10.1183/23120541.00034-2018

Bousquet, P. J., Chinn, S., Janson, C., Kogevinas, M., Burney, P., Jarvis, D., \& European Community Respiratory Health Survey I (2007). Geographical variation in the prevalence of positive skin tests to environmental aeroallergens in the European Community Respiratory Health Survey I. Allergy, 62(3), 301309. https://doi.org/10.1111/j.1398-9995.2006.01293.x

Bousquet, J., Kiley, J., Bateman, E. D., Viegi, G., Cruz, A. A., Khaltaev, N., Aït Khaled, N., Baena-Cagnani, C. E., Barreto, M. L., Billo, N., Canonica, G. W., Carlsen, K. H., Chavannes, N., Chuchalin, A., Drazen, J., Fabbri, L. M., Gerbase, M. W., Humbert, M., Joos, G., Masjedi, M. R., Makino, S., To, T., \& Zhi, L. (2010). Prioritised research agenda for prevention and control of chronic respiratory diseases. The European respiratory journal, 36(5), 9951001. https://doi.org/10.1183/09031936.00012610

Brunsdon, C., Fotheringham, A. S., \& Charlton, M. E. (1996). Geographically weighted regression: a method for exploring spatial nonstationarity. Geographical analysis, 28(4), 281-298. https://doi.org/10.1111/j.15384632.1996.tb00936.x

Cortés, X., Soriano, J. B., Sánchez-Ramos, J. L., Azofra, J., Almar, E., \& Ramos, J. (1998). European study of asthma. Prevalence of atopy in young adults of 5 areas in Spain. Spanish Group of European Asthma Study. Medicina clínica, 111(15), 573-577.

Cromley, E. K., \& McLafferty, S. L. (2011). GIS and public health. Guilford Press.

Buist, A. S., McBurnie, M. A., Vollmer, W. M., Gillespie, S., Burney, P., Mannino, D. M., Menezes, A. M., Sullivan, S. D., Lee, T. A., Weiss, K. B., Jensen, R. L., Marks, G. B., Gulsvik, A., Nizankowska-Mogilnicka, E., \& BOLD Collaborative Research Group (2007). International variation in the prevalence of COPD (the BOLD Study): a population-based prevalence study. Lancet (London, England), 370(9589), 741-750. https://doi.org/10.1016/S0140-6736(07)613774

Darrow, L. A., Hess, J., Rogers, C. A., Tolbert, P. E., Klein, M., \& Sarnat, S. E. (2012). Ambient pollen concentrations and emergency department visits for asthma and wheeze. The Journal of allergy and clinical immunology, 130(3), 630-638.e4. https://doi.org/10.1016/j.jaci.2012.06.020 
Dahlgren, G., \& Whitehead, M. (1991). Policies and strategies to promote social equity in health. Stockholm: Institute for future studies, 1-69.

Diab, N., Gershon, A. S., Sin, D. D., Tan, W. C., Bourbeau, J., Boulet, L. P., \& Aaron, S. D. (2018). Underdiagnosis and overdiagnosis of chronic obstructive pulmonary disease. American journal of respiratory and critical care medicine, 198(9), 1130-1139. https://doi.org/10.1164/rccm.201804-0621Cl

Douglas, J. A., Archer, R. S., \& Alexander, S. E. (2019). Ecological determinants of respiratory health: Examining associations between asthma emergency department visits, diesel particulate matter, and public parks and open space in Los Angeles, California. Preventive medicine reports, 14, 100855. https://doi.org/10.1016/j.pmedr.2019.100855

Dodd, K. E., Wood, J., \& Mazurek, J. M. (2020). Mortality Among Persons with Both Asthma and Chronic Obstructive Pulmonary Disease Aged $\geq 25$ Years, by Industry and Occupation - United States, 1999-2016. MMWR. Morbidity and mortality weekly report, 69(22), 670-679. https://doi.org/10.15585/mmwr.mm6922a3

Ellison-Loschmann, L., Sunyer, J., Plana, E., Pearce, N., Zock, J. P., Jarvis, D., Janson, C., Antó, J. M., Kogevinas, M., \& European Community Respiratory Health Survey (2007). Socioeconomic status, asthma and chronic bronchitis in a large community-based study. The European respiratory journal, 29(5), 897-

905. https://doi.org/10.1183/09031936.00101606

European Community Respiratory Health Survey II Steering Committee [ECRHS] (2002). The European Community Respiratory Health Survey II. The European respiratory journal, 20(5), 10711079. https://doi.org/10.1183/09031936.02.00046802

Fotheringham, A.S., Brunsdon, C., \& Charlton, M.E. (2002). Geographically Weighted Regression: The Analysis of Spatially Varying Relationships. Wiley, Chichester.

Executive Committee GEMA 2009 [GEMA] (2010). GEMA 2009 (Spanish guideline on the management of asthma). Journal of investigational allergology \& clinical immunology, 20 Suppl 1, 1-59.

Gayle, A. V., Quint, J. K., \& Fuertes, E. I. (2021). Understanding the relationships between environmental factors and exacerbations of COPD. Expert review of respiratory medicine, 15(1), 39-50.

https://doi.org/10.1080/17476348.2020.1801426

George, M., Bruzzese, J. M., \& Matura, L. A. (2017). Climate Change Effects on Respiratory Health: Implications for Nursing. Journal of nursing scholarship: an official publication of Sigma Theta Tau International Honor Society of Nursing, 49(6), 644-652. https://doi.org/10.1111/jnu.12330

Gershon, A. S., Dolmage, T. E., Stephenson, A., \& Jackson, B. (2012). Chronic obstructive pulmonary disease and socioeconomic status: a systematic review. COPD: Journal of Chronic Obstructive Pulmonary Disease, 9(3), 216226. https://doi.org/10.3109/15412555.2011.648030.

Gibson, G. J., Loddenkemper, R., Lundbäck, B., \& Sibille, Y. (2013). Respiratory health and disease in Europe: the new European Lung White Book. The European respiratory journal, 42(3), 559-

563. https://doi.org/10.1183/09031936.00105513

Page 19/28 
GBD 2015 Chronic Respiratory Disease Collaborators (2017). Global, regional, and national deaths, prevalence, disability-adjusted life years, and years lived with disability for chronic obstructive pulmonary disease and asthma, 1990-2015: a systematic analysis for the Global Burden of Disease Study 2015. The Lancet. Respiratory medicine, 5(9), 691-706. https://doi.org/10.1016/S22132600(17)30293-X

Global Burden of Disease Collaborative Network. Global Burden of Disease Study 2016 (GBD 2016) Incidence, Prevalence, and Years Lived with Disability 1990-2016. Seattle, United States: Institute for Health Metrics and Evaluation (IHME), 2017.

Guo, B., Wang, Y., Pei, L., Yu, Y., Liu, F., Zhang, D., Wang, X., Su, Y., Zhang, D., Zhang, B., \& Guo, H. (2021). Determining the effects of socioeconomic and environmental determinants on chronic obstructive pulmonary disease (COPD) mortality using geographically and temporally weighted regression model across Xi'an during 2014-2016. The Science of the total environment, 756, 143869. https://doi.org/10.1016/j.scitotenv.2020.143869

Halbert, R. J., Natoli, J. L., Gano, A., Badamgarav, E., Buist, A. S., \& Mannino, D. M. (2006). Global burden of COPD: systematic review and meta-analysis. The European respiratory journal, 28(3), 523-

532. https://doi.org/10.1183/09031936.06.00124605

Hansel, N. N., McCormack, M. C., \& Kim, V. (2016). The Effects of Air Pollution and Temperature on COPD. COPD, 13(3), 372- 379. https://doi.org/10.3109/15412555.2015.1089846

Health Effects Institute (2019). State of Global Air 2019: Special Report on global exposure to air pollution and its disease burden. Boston, MA: Health Effects Institute. https://www.stateofglobalair.org/sites/default/files/soga_2019_report.pdf

Hurvich, C. M., Simonoff, J. S., \& Tsai, C. L. (1998). Smoothing parameter selection in nonparametric regression using an improved Akaike information criterion. Journal of the Royal Statistical Society: Series B (Statistical Methodology), 60(2), 271-293. 60, 271-293. https://doi.org/10.1111/1467-9868.00125

Jenkins, C. R., Celli, B., Anderson, J. A., Ferguson, G. T., Jones, P. W., Vestbo, J., Yates, J. C., \& Calverley, P. M. (2012). Seasonality and determinants of moderate and severe COPD exacerbations in the TORCH study. The European respiratory journal, 39(1), 38-45. https://doi.org/10.1183/09031936.00194610

José, B. P., Camargos, P. A., Cruz Filho, Á. A., \& Corrêa, R. (2014). Diagnostic accuracy of respiratory diseases in primary health units. Revista da Associacao Medica Brasileira (1992), 60(6), 599-

612. https://doi.org/10.1590/1806-9282.60.06.021

Kauhl, B., Maier, W., Schweikart, J., Keste, A., \& Moskwyn, M. (2018). Who is where at risk for Chronic Obstructive Pulmonary Disease? A spatial epidemiological analysis of health insurance claims for COPD in Northeastern Germany. PloS one, 13(2), e0190865. https://doi.org/10.1371/journal.pone.0190865

Koppelman G. H. (2006). Gene by environment interaction in asthma. Current allergy and asthma reports, 6(2), 103-111. https://doi.org/10.1007/s11882-006-0047-y

Kitinoja, M. A., Hugg, T. T., Siddika, N., Rodriguez Yanez, D., Jaakkola, M. S., \& Jaakkola, J. (2020). Short-term exposure to pollen and the risk of allergic and asthmatic manifestations: a systematic review and meta-analysis. BMJ open, 10(1), e029069. https://doi.org/10.1136/bmjopen-2019-029069

Page 20/28 
Kumarihamy, R. M. K., \& Tripathi, N. K. (2019). Geostatistical predictive modelling for asthma and chronic obstructive pulmonary disease using socioeconomic and environmental determinants. Environmental monitoring and assessment, 191(2), 1-21. https://doi.org/10.1007/s10661-019-7417-0

Lozano, R., Naghavi, M., Foreman, K., Lim, S., Shibuya, K., Aboyans, V., Abraham, J., Adair, T., Aggarwal, R., Ahn, S. Y., Alvarado, M., Anderson, H. R., Anderson, L. M., Andrews, K. G., Atkinson, C., Baddour, L. M., Barker-Collo, S., Bartels, D. H., Bell, M. L., Benjamin, E. J., ... Memish, Z. A. (2012). Global and regional mortality from 235 causes of death for 20 age groups in 1990 and 2010: a systematic analysis for the Global Burden of Disease Study 2010. Lancet (London, England), 380(9859), 2095-2128. https://doi.org/10.1016/S0140-6736(12)61728-0

Lundbäck, B., Backman, H., Lötvall, J., \& Rönmark, E. (2016). Is asthma prevalence still increasing? Expert review of respiratory medicine, 10(1), 39-51. https://doi.org/10.1586/17476348.2016.1114417

Marmot, M., Allen, J., Bell, R., Bloomer, E., \& Goldblatt, P. (2012). WHO European review of social determinants of health and the health divide. The Lancet, 380(9846), 1011-1029. https://doi.org/10.1016/S0140-6736(12)61228-8

Martínez-Moragón, E., Serra-Batllés, J., De Diego, A., Palop, M., Casan, P., Rubio-Terrés, C., ... \& AsmaCost Study Group. (2009). Economic cost of treating the patient with asthma in Spain: the AsmaCost study. Archivos de Bronconeumología ((English Edition)), 45(10), 481-486.

Mathers, C. D., \& Loncar, D. (2006). Projections of global mortality and burden of disease from 2002 to 2030 . PLoS medicine, 3(11), e442. https://doi.org/10.1371/journal.pmed.0030442

Miravitlles, M., Murio, C., Guerrero, T., \& Gisbert, R. (2003). Costs of chronic bronchitis and COPD: a 1-year follow-up study. Chest, 123(3), 784-791. https://doi.org/10.1378/chest.123.3.784

Miravitlles, M., Soriano, J. B., García-Río, F., Muñoz, L., Duran-Tauleria, E., Sanchez, G., Sobradillo, V., \& Ancochea, J. (2009). Prevalence of COPD in Spain: impact of undiagnosed COPD on quality of life and daily life activities. Thorax, 64(10), 863-868. https://doi.org/10.1136/thx.2009.115725

Miravitlles, M., Soler-Cataluña, J. J., Calle, M., Molina, J., Almagro, P., Quintano, J. A., ... \& Ancochea, J. (2014). Guía española de la EPOC (GesEPOC). Actualización 2014. Archivos de bronconeumologia, 50, 1-

16. https://doi.org/10.1016/S0300-2896(14)70070-5

Nakaya, T., Fotheringham, A. S., Brunsdon, C., y Charlton, M. (2005). Geographically weighted Poisson regression for disease association mapping. Statistics in medicine, 24(17), 2695-2717. https://doi.org/10.1002/sim.2129

Plaza, V., Alonso, S., Alvarez, C., Gomez-Outes, A., Gómez, F., López, A., Molina, J., Pellegrini, F. J., Plaza, J., Quintano, J. A., Quirce, S., Sanz, J. S., Soler, R., \& Villa, J. S. (2016). SPANISH GUIDELINE ON THE MANAGEMENT OF ASTHMA. Journal of investigational allergology \& clinical immunology, 26 Suppl 1(Suppl 1), 192. https://doi.org/10.18176/jiaci.0065

Rajan, S., Gogtay, N. J., Konwar, M., \& Thatte, U. M. (2020). The global initiative for asthma guidelines (2019): change in the recommendation for the management of mild asthma based on the SYGMA-2 trial - A critical appraisal. Lung India: official organ of Indian Chest Society, 37(2), 169-173.

https://doi.org/10.4103/lungindia.lungindia_308_19

Page 21/28 
Raju, S., Keet, C. A., Paulin, L. M., Matsui, E. C., Peng, R. D., Hansel, N. N., \& McCormack, M. C. (2019). Rural Residence and Poverty Are Independent Risk Factors for Chronic Obstructive Pulmonary Disease in the United States. American journal of respiratory and critical care medicine, 199(8), 961969. https://doi.org/10.1164/rccm.201807-13740C

Sáenz, J. G., Jiménez, J. Q., Requena, A. H., Béjar, M. G., Callejas, M. G., Urunuela, M. Z., ... \& García, R. H. (2014). Enfermedad pulmonar obstructiva crónica: morbimortalidad e impacto sanitario. SEMERGEN-Medicina de Familia, 40(4), 198-204. https://doi.org/10.1016/j.semerg.2013.12.009

Scherber, K., Langner, M., \& Endlicher, W. (2014). Spatial analysis of hospital admissions for respiratory diseases during summer months in Berlin taking bioclimatic and socioeconomic aspects into account. DIE ERDE-Journal of the Geographical Society of Berlin, 144, 217-237. https://doi.org/10.12854/erde-144-16

Schulz, A., \& Northridge, M. E. (2004). Social determinants of health: implications for environmental health promotion. Health education \& behavior, 31(4), 455-471. https://doi.org/10.1177/1090198104265598

Sobradillo-Peña, V., Miravitlles, M., Gabriel, R., Jiménez-Ruiz, C. A., Villasante, C., Masa, J. F., Viejo, J. L., \& Fernández-Fau, L. (2000). Geographic variations in prevalence and underdiagnosis of COPD: results of the IBERPOC multicentre epidemiological study. Chest, 118(4), 981-989. https://doi.org/10.1378/chest.118.4.981

Soriano, J. B., Ancochea, J., Miravitlles, M., García-Río, F., Duran-Tauleria, E., Muñoz, L., Jiménez-Ruiz, C. A., Masa, J. F., Viejo, J. L., Villasante, C., Fernández-Fau, L., Sánchez, G., \& Sobradillo-Peña, V. (2010). Recent trends in COPD prevalence in Spain: a repeated cross-sectional survey 1997-2007. The European respiratory journal, 36(4), 758-765. https://doi.org/10.1183/09031936.00138409

Soumagne, T., Degano, B., Guillien, A., Annesi-Maesano, I., Andujar, P., Hue, S., Adotevi, O., Jouneau, S., Botebol, M., Laplante, J. J., Roche, N., \& Dalphin, J. C. (2020). Characterization of chronic obstructive pulmonary disease in dairy farmers. Environmental research, 188, 109847. https://doi.org/10.1016/j.envres.2020.109847

Sunyer, J., Spix, C., Quénel, P., Ponce-de-León, A., Pönka, A., Barumandzadeh, T., Touloumi, G., Bacharova, L., Wojtyniak, B., Vonk, J., Bisanti, L., Schwartz, J., \& Katsouyanni, K. (1997). Urban air pollution and emergency admissions for asthma in four European cities: the APHEA Project. Thorax, 52(9), 760-

765. https://doi.org/10.1136/thx.52.9.760

Syamlal, G., Bhattacharya, A., \& Dodd, K. E. (2020). Medical Expenditures Attributed to Asthma and Chronic Obstructive Pulmonary Disease Among Workers-United States, 2011-2015. Morbidity and Mortality Weekly Report, 69(26), 809. http://dx.doi.org/10.15585/mmwr.mm6926a1

The Global Asthma Report 2018. Auckland, New Zealand: Global Asthma Network, 2018.

To, T., Stanojevic, S., Moores, G., Gershon, A. S., Bateman, E. D., Cruz, A. A., \& Boulet, L. P. (2012). Global asthma prevalence in adults: findings from the cross-sectional world health survey. BMC public health, 12, 204. https://doi.org/10.1186/1471-2458-12204

Urrutia, I., Aguirre, U., Sunyer, J., Plana, E., Muniozguren, N., Martínez-Moratalla, J., Payo, F., Maldonado, J.A., Anto, J. M. \& “El grupo español del Estudio Europeo de Salud Respiratoria de la Comunidad Europea” (2007). Cambios 
en la prevalencia de asma en la población española del Estudio de Salud Respiratoria de la Comunidad Europea (ECRHS-II). Archivos de Bronconeumología, 43(8), 425-430. https://doi.org/10.1157/13108781

Vogelmeier, C. F., Criner, G. J., Martinez, F. J., Anzueto, A., Barnes, P. J., Bourbeau, J., Celli, B. R., Chen, R., Decramer, M., Fabbri, L. M., Frith, P., Halpin, D. M., López Varela, M. V., Nishimura, M., Roche, N., Rodriguez-Roisin, R., Sin, D. D., Singh, D., Stockley, R., Vestbo, J., \& Agustí, A. (2017). Global Strategy for the Diagnosis, Management, and Prevention of Chronic Obstructive Lung Disease 2017 Report. GOLD Executive Summary. American journal of respiratory and critical care medicine, 195(5), 557-582. https://doi.org/10.1164/rccm.201701-0218PP

World Health Organization (2010). World health statistics 2008. Retrieved from: http://www.who.int/whosis/whostat/EN_WHS08_Full.pdf.

World Health Organization. (2016). Ambient air pollution: a global assessment of exposure and burden of disease. World Health Organization. Retrieved from: https://apps.who.int/iris/handle/10665/250141.

\section{Figures}




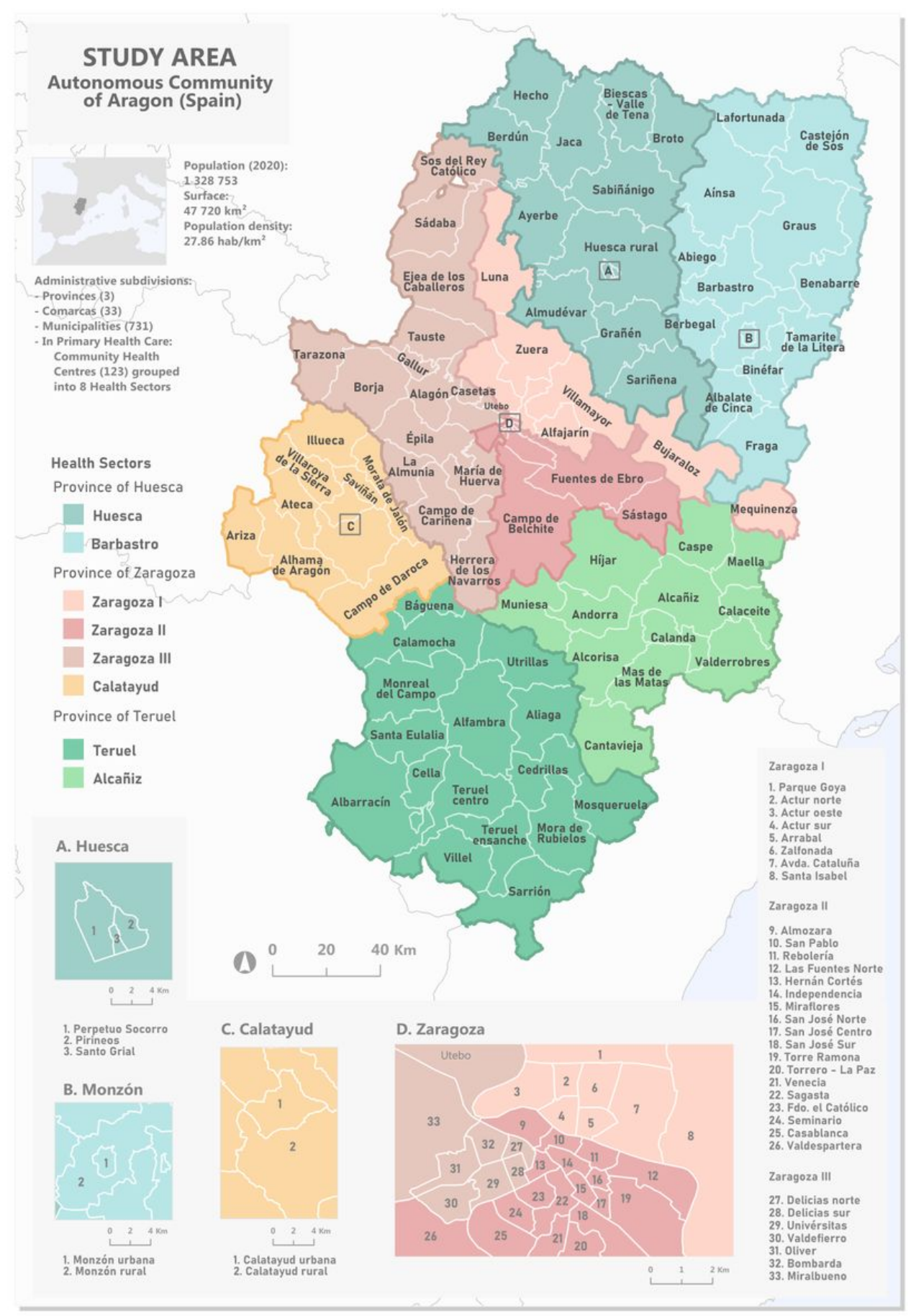

\section{Figure 1}

Study area, administrative subdivisions and observational unit. 


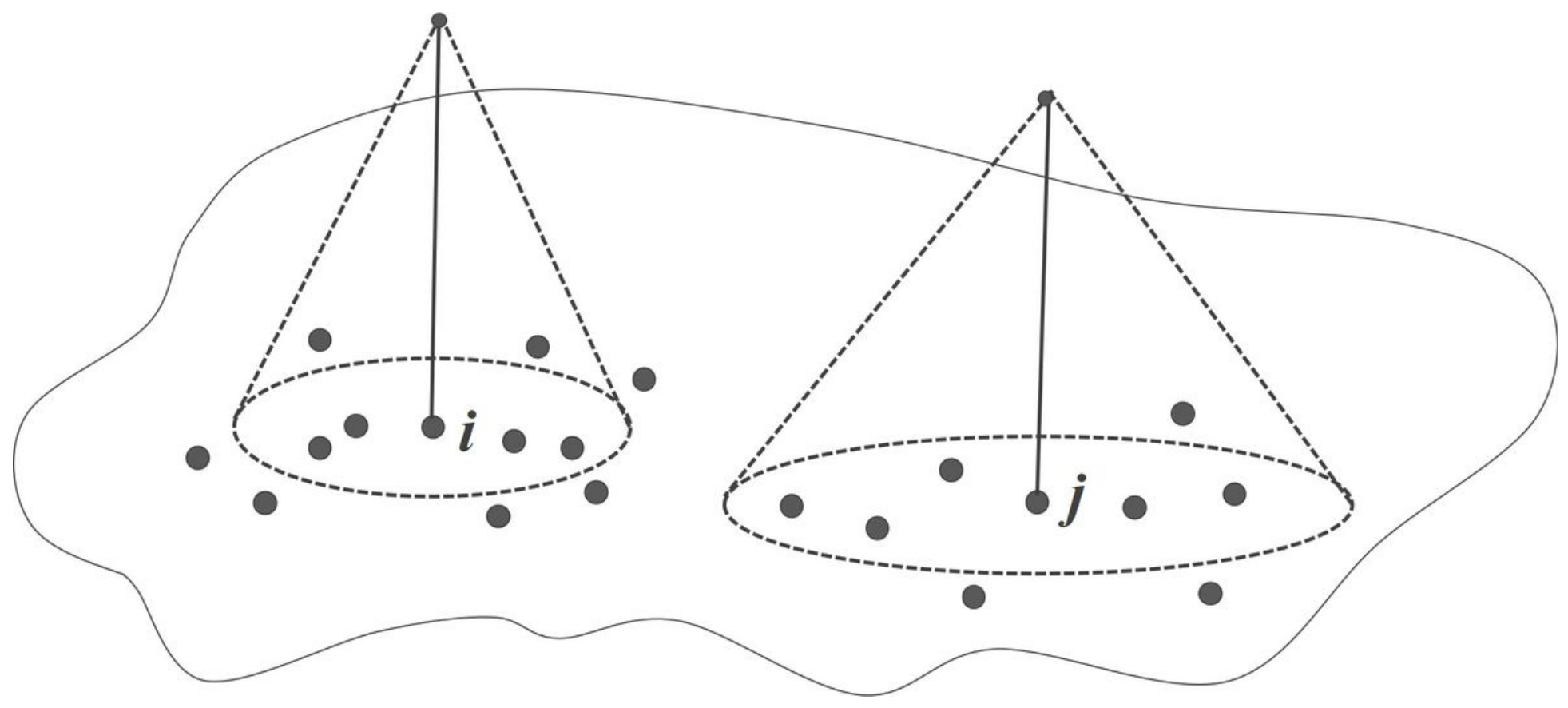

Figure 2

Illustration of adaptive kernel operation (adapted from Fotheringham et al., 2002). 


\section{PREVALENCE OF ASTHMA AND COPD IN ADULTS \\ OF 16 YEARS AND OVER}

COMMUNITY HEALTH CENTERS (CHCS), ARAGON, 2017
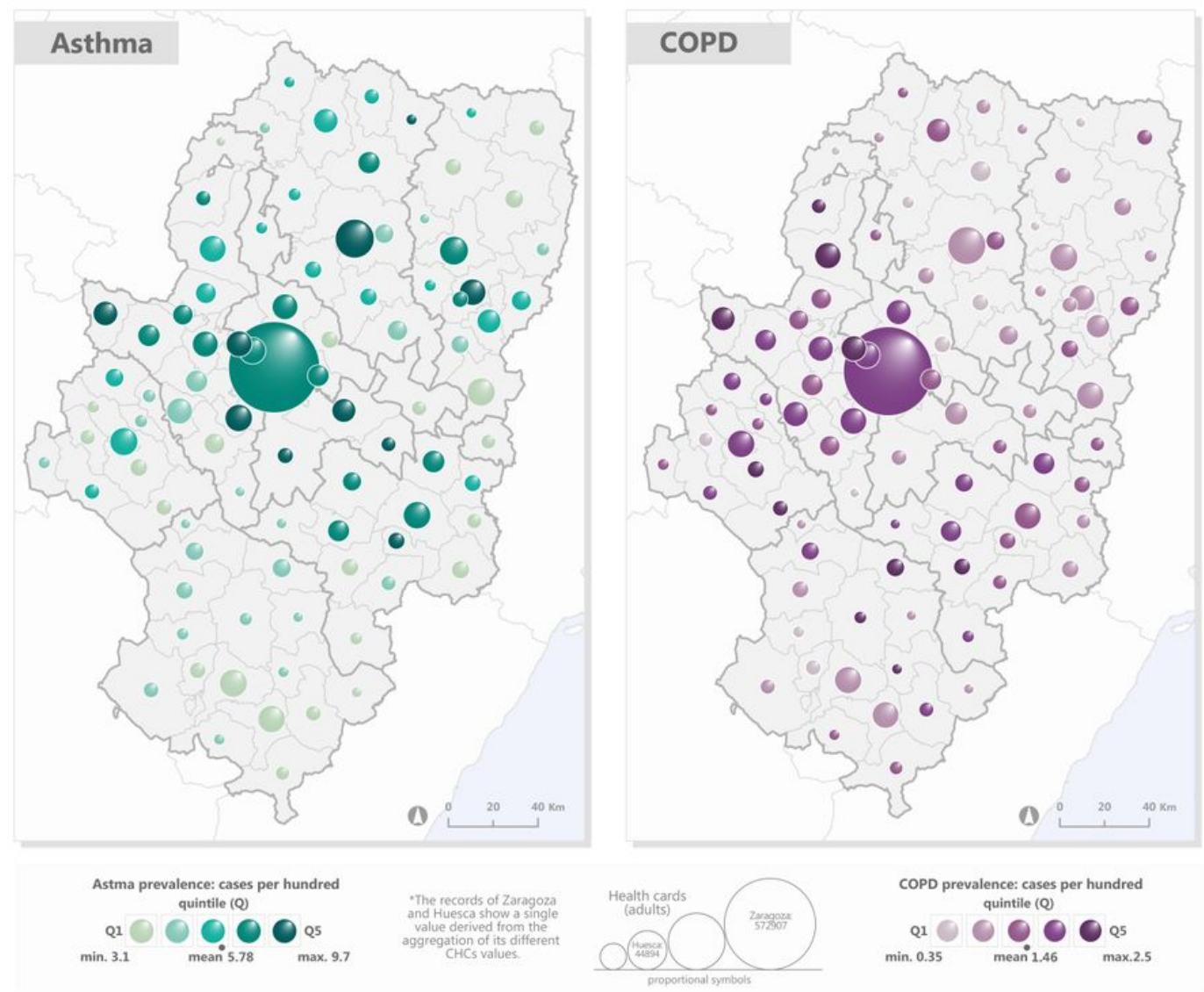

$$
\begin{aligned}
& \text { COPD prevalence: cases per hundred } \\
& \text { quintile (Q) } \\
& \text { min. 0.35 mean 1.46 } 10 \text { max.2.5 }
\end{aligned}
$$

URBAN CHCs: ZARAGOZA AND HUESCA
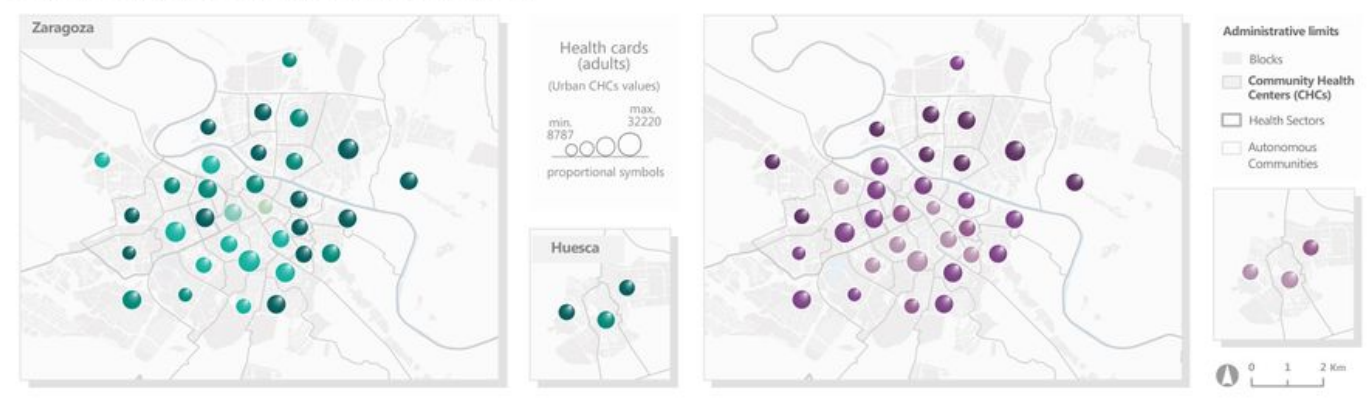

Figure 3

Spatial distribution of asthma and COPD prevalence. 


\section{FUNCTIONALITY, SOCIODEMOGRAPHIC AND CLIMATIE VARIABLES DERIVED FROM PRINCIPAL COMPONENT ANALYSIS}

\section{PCA 1 - Functionality and sociodemographic variables}
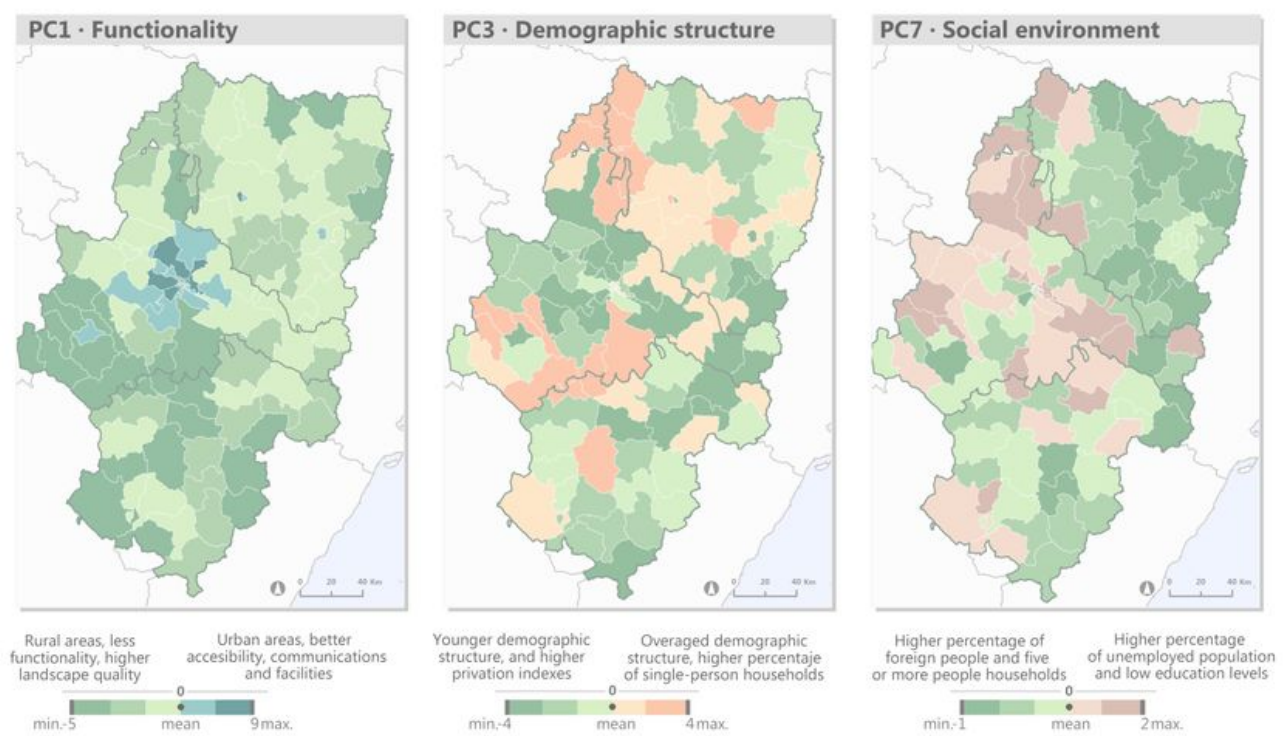

PCA 2 - Climate variables
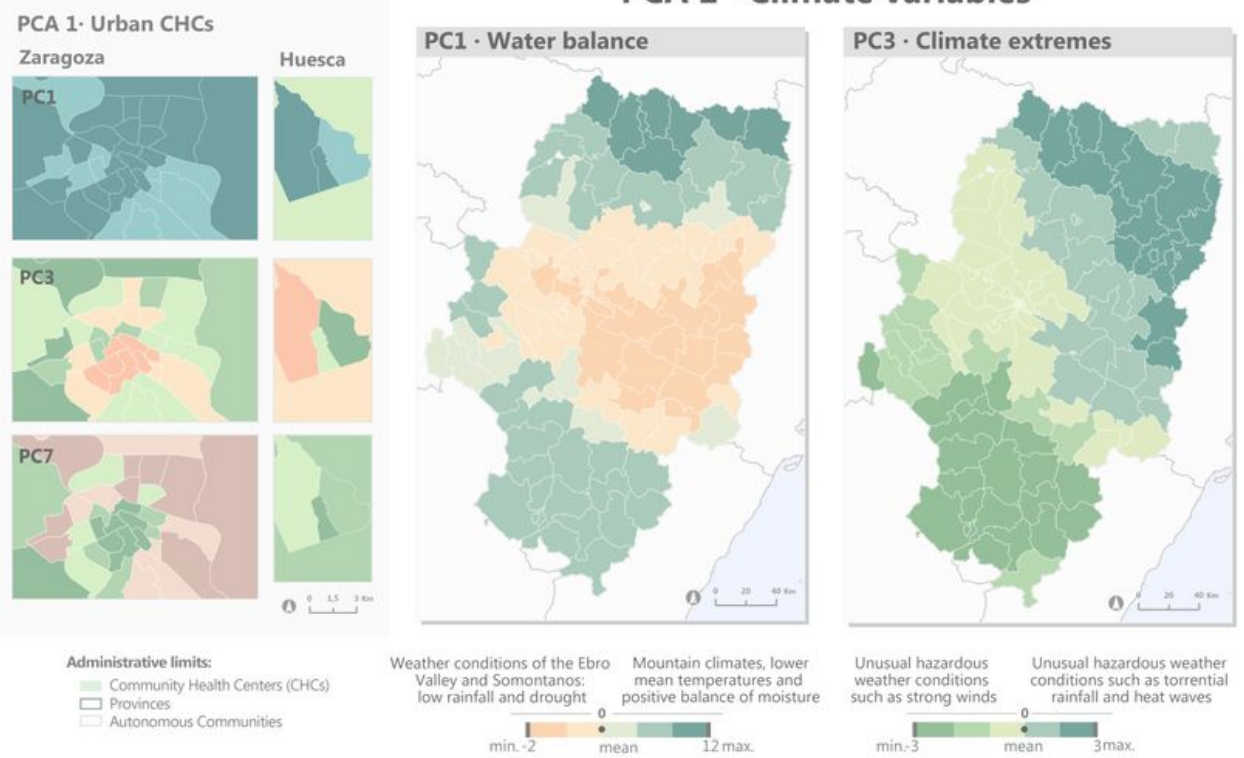

Figure 4

Spatial distribution of asthma and COPD prevalence. 


\section{GEOGRAPHICALLY WEIGHTED REGRESSION: SIGNIFICANCE MODEL COVARIATES AND LOCAL $\mathbf{R}^{2}$}

Model 1 - Asthma

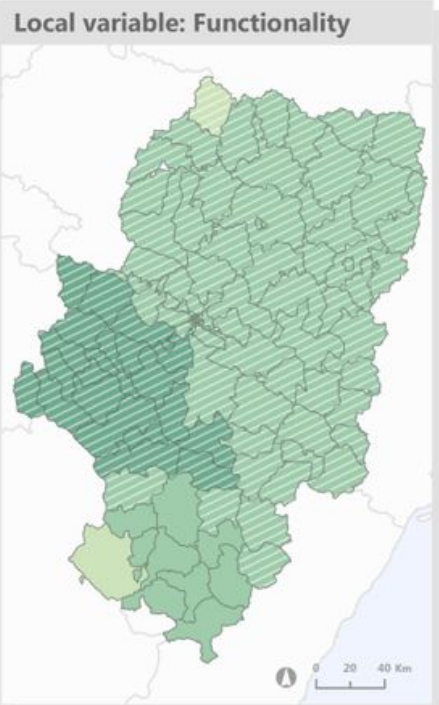

Local $\mathbf{R}^{2}$
Model 2 - Asthma

Local variable: (i) Water balance

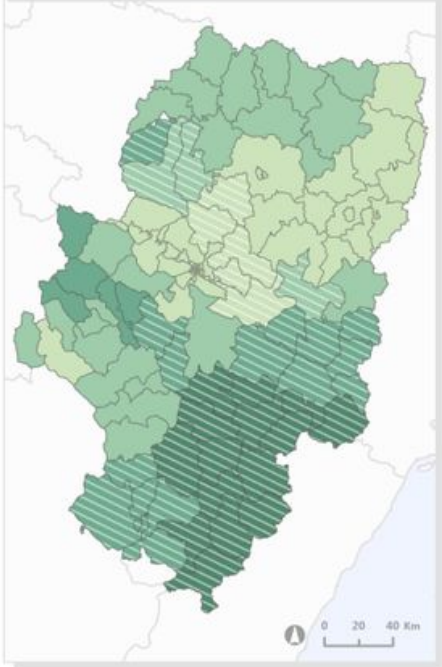
Local $\mathbf{R}^{2}$ $\begin{array}{lllll}0.2 & 0.4 & 0.6 & {[\max .} & 0.69\end{array}$

Administrative limits

Community Health Centers (CHCs)

Local $\mathbf{R}^{2}$

Model $3 \cdot$ COPD

Local variable: Functionality

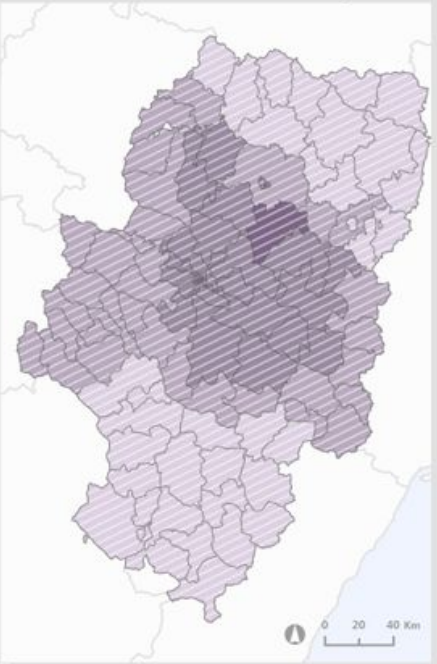

$0.20 .4 \quad 0.6 \quad[\max .0 .62]$

Significance $p<0.05$ Positive direction Negative direction

Autonomous Communities

\section{Figure 5}

Spatial distribution of significance of model covariates and local R2. 